\title{
Webern's Op. 12, No. 2, Die geheimnisvolle Flöte: Text Setting, Form, and Pitch Orthography ${ }^{1}$
}

\author{
Yi-Cheng Daniel Wu \\ Soochow University School of Music (China) \\ 199 Renai Rd., Higher Education Town \\ Suzhou, Jiangsu Province, China, 215123 \\ E-mail: yichengwu@suda.edu.cn
}

(Received: December 2017; accepted: March 2018)

\begin{abstract}
In tonal music, pitch orthography reflects different structural and functional meanings of notes in various contextual and textural settings such as harmony, melody, and voice leading. At the turn of the twentieth century, many composers attempt to progress beyond the confines of traditional tonality, whose works, as generally perceived by most analysts nowadays, treat the twelve chromatic notes as the twelve enharmonically equivalent pitch-classes and thus present "the dissolution of ... [the] notational conventions of earlier times" (Gillies 1993, 43). Contrary to this general sentiment regarding orthography, the present paper brings the significance of pitch notation into sharper focus by investigating its crucial role in the course of the text setting and form in Webern's op. 12, no. 2. I will demonstrate how Webern utilizes orthography to reinforce the structure of the text and the narrative of form, assisting the analyst in considering notation as a core element while examining the pitch structure of the early twentieth-century music.
\end{abstract}

Keywords: Webern, atonal song, form, pitch orthography, text setting

\section{Introduction}

This paper examines the issue of pitch orthography in relation to the text setting and the narrative of form in Webern's op. 12, no. 2, Die geheimnisvolle Flöte. Webern composed this atonal song in 1917, in a period (1914-1926) when he

1. An earlier version of this article was presented at the 9th European Music Analysis Conference (Université de Strasbourg, Départment Musique, June 29, 2017). I would like to thank Philip Stoecker, Martha Hyde, Kathleen Marien, and Eugena Riehl for their helpful suggestions and comments. 
was prolifically writing Lieder (opp. 12-19). ${ }^{2}$ Prominent features in this piece - the obvious absent repetitions of themes in music ${ }^{3}$ and verses in the poem perhaps suggest it is through-composed. However, several gestures create what Robert Morgan would refer to as the "faint suggestion of reprise"4 that may strongly hint the song being reminiscent of a more typical ternary form ABA'. Example 1 shows how the vocal phrase in the last part of the song (mm. 19-21) recaptures the six essential features in the opening vocal phrase (mm. 3-4), potentially implying the process of a formal reprise and consequently alluding the song's overall architecture to ABA'.

The first is the similarity of the textual structure between the two phrases. Their second words both end with the same syllable "nem" followed by "Abend." This strong textual similarity is probably the reason for Webern's use of following five common features to set both texts to music. Features (2), (3), and (4) are quite apparent - both phrases begin with the same pitch $\mathrm{G}$ articulated by the dynamics $p$, which are superimposed on a similar rhythmic pattern (the pattern in the last vocal phrase more or less doubles the rhythmic values in the pattern of the first phrase). Also, both rhythmic pattern stresses on the first syllable of the word "A-bend" by using the longest duration therein. In (5), we find another type of musical emphasis on the word "Abend" - an interval pattern. Webern sets "Abend" on a large leap in both phrases, and each leap is preceded, prepared by an ascending whole tone. Feature (6) contains two traits. One is the appearance of set-class 3-1 in both phrases ${ }^{5}$ it occurs at the beginning of the first phrase and the

2. Webern's utter interest in writing songs in this particular period is probably a reaction to his pre-war instrumental miniatures opp. 7, 9, 10, and 11. All these instrumental pieces characterize the extreme brevity of concise forms. For comparison between his songs and pre-war miniatures, see Hans and Rosaleen Moldenhauer, Anton von Webern: A Chronicle of His Life and Work (New York: Alfred A. Knopf, 1979), 267; Anne C. Shreffler, "Introduction: Webern and Lyric Expression," in Webern and the Lyric Impulse: Songs and Fragments on Poems of Georg Trakl (Oxford: Clarendon Press, 1994), 11; and Allen Forte, "The New Lieder: Four Songs for Voice and Piano, opus 12," in The Music of Anton Webern (New Haven: Yale University Press, 1998), 252.

3. This athematic style is developed in his pre-war instrumental pieces, in which repetitions or developments of a theme are strictly avoided. Rather, the music is put together "from a number of highly individualized elements, all more or less equal in weight and importance." Robert Morgan, "The Atonal Revolution," in Twentieth-Century Music: A History of Musical Style in Modern Europe and America (New York: W. W. Norton \& Company, 1991), 82. For other related discussion, see Richard Crocker, A History of Musical Style (New York: Dover Publications, 1986), 509; Luciano Berio, Remembering the Future: The Charles Eliot Norton Lectures (Cambridge, MA: Harvard University Press, 2006), 18; Joseph Auner, "Making New Musical Languages," Music in the Twentieth and Twenty-First Centuries (New York: W. W. Norton \& Company, 2013), 51.

4. For instance in Webern's Four Pieces for Violin and Piano (op. 7, no. 3), although there is no literal repetition of themes and motives, the ending subtly emphasizes the opening pitch A accompanied by some crucial structural intervals in the beginning of the piece suggests a process of reprise. Robert Morgan, "The Atonal Revolution," 82.

5. As Forte observes ("The New Lieder: Four Songs for Voice and Piano, Opus 12," 261-262), trichord 3-1 is an important structural melodic material in this song, which is derived from what he defines as the magic rectangle (ibid., 261). This rectangle is created by the three consecutive pentachords $5-21 \mathrm{in} \mathrm{m}$. 2 in the piano prelude (see Example 2); they form a unique ordered pitch-class set of $321 / 765 / 210 / \mathrm{t} 98 / 654$. Forte discovers that Webern's selections of harmonies in this piece are primarily subsets derived from this rectangle. For more discussion about Webern's magic rectangle, also see Robert Gauldin,"The Magic Squares of the Third Movement of Webern's Concerto Op. 24," In Theory Only 2 (February 1977), 32-42. Besides 3-1, the 
ExAmPLe 1 Die geheimnisvolle Flöte: the first and last vocal phrases and the faint suggestions of reprise

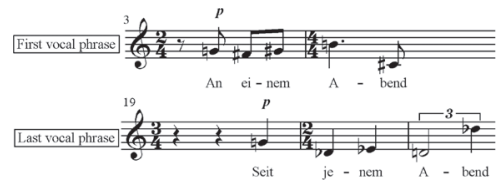

Six features associate these two vocal phrases:

(1) The similarity of the textual structure

First vocal phrase An einem Abend

Last vocal phrasc Seit jenem Abend

(2) The same pitch $G$ at the beginning of each phrase

(3) The same dynamics $p$

(4) Similar rhythmic arrangement

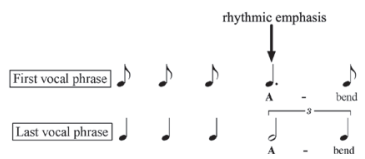

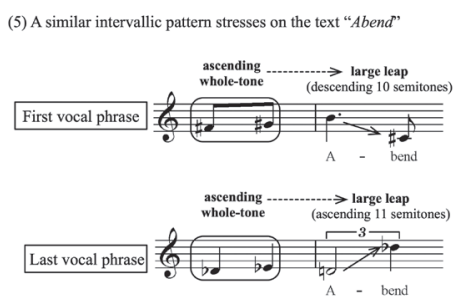

(6) Trichord 3-1 and the inversion ally related accidentals

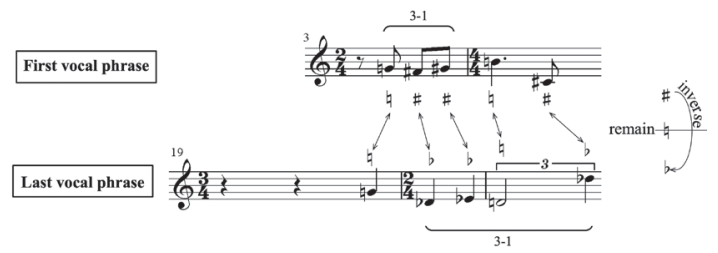

end of the last phrase. The other trait is particularly and analytically intriguing. All the accidentals are "inversionally" related around the natural sign. That is, the naturals remain, and the sharps are notated as flats. This finding leads me to speculate that perhaps Webern has a unique system to spell the twelve chromatic notes and further applies his pitch orthography to articulate not only musical form but also text setting.

Although text setting and musical form are the common and major concerns in the current analytical literature of Webern's songs, ${ }^{6}$ incorporating these is-

Viennese trichord 016 (3-5) is another structurally important harmony that appears throughout the piece; see Miguel Roig-Francoli, Understanding Post-Tonal Music (New York: McGraw-Hill Higher Education, 2008), 12; and Henry Martin, "Seven Steps to Heaven: A Species Approach to Twentieth Century Analysis and Composition," Perspective of New Music 38/1 (Winter 2000), 154.

6. Relevant works include David Griffiths, Song Writing: Poetry, Webern and Musical Modernism, Ph.D. Diss. (University of London, King's College, 1993); Robert Morgan, "Anton Webern (1883-1945)," in Anthology of Twentieth-Century Music (New York: W. W. Norton \& Company), 174-180; Laurie Jean Reinhardt, From Poet's Voice to Composer's Muse: Text and Music in Webern's Jone Settings, Ph.D. Diss. (University of North Carolina at Chapel Hill, 1995); Allen Forte, "The Golden Thread: Octatonic Music in Anton Webern's Early Songs, with Certain Historical Reflections," in Webern Studies, ed. by Kathryn Bailey (Cambridge: Cambridge University Press, 1996), 74-110; Robert Wason, “A Pitch-class Motive in Webern's George Lieder, Op. 3,” in Webern Studies (ibid.), 111-134; Christopher Wintle, "Webern’s Lyric Character," in Webern Studies (ibid.), 229-263; Susanne Rode-Breyman, “»...gathering the divine from the earthly...«: Ferdinand Avenarius and his Significance for Anton Webern's Early Settings of Lyric Poetry," in Webern Studies (ibid.), 1-31; Jerry M. Cain, "Anton Webern's Lied Settings of Poems by Karl Kraus," Ph.D. Diss. (Florida State University, 2003); Lorian Meyer-Wendt, "Anton Webern's Musical Realization of Goethe's Urpflanze Concept in Drei Lieder, Op. 18," MA Thesis (Florida State University, 2004) and William David Sanford, "Anton Webern's Schweigt auch die Welt from the Second Cantata opus 31: A Combination of Text-Setting and Serialism," Sonus: A Journal of Investigation into Global Musical Possibilities 34/2 (Spring 2014), 56-70. Contrarily, some analysts, such as Heinz-Klaus Metzger ("Analysis of Sacred Song, Op. 15, No. 4," in Die 
sues with the subject of pitch orthography remains untouched. ${ }^{7}$ At the turn of the twentieth century, many composers attempted to progress beyond the confines of traditional tonality. Thus, their works, as generally perceived by most analysts nowadays, treat the twelve chromatic notes as the twelve enharmonically equivalent pitch-classes and so present "the dissolution of ... [the] notational conventions of earlier times." ${ }^{8}$ However, contrary to this general sentiment regarding orthography, the close investigation of the accidentals in Example 1 reveals the fact that Webern may carefully consider pitch orthography as one of the structural elements, which articulates his form and text setting. Inspired by this issue, the present paper brings the significance of pitch notation into sharper focus by studying its crucial role in the course of the form and text setting in Webern's Die geheimnisvolle Flöte. I will demonstrate the way he utilizes orthography to reinforce the narrative of form and the structure of the text, assisting the analyst in considering notation as a core element while examining the pitch structure of the early 20th-century music. I have organized this paper into three sections - the analysis of the text, its setting, and the piano accompaniment. The issues of form and pitch orthography will be constantly addressed and investigated in various situations throughout the last two sections.

Reihe 2: Anton Webern, edited by Herbert Eimert and Karlheinz Stockhausen, translated by Leo Black [Bryn Mawr, PA: Theodore Presser Company, 1958], 75-80) treat vocal line as an instrument, disregarding the text while studying Webern's songs. Other studies, although focusing on different composers in the twentieth and twenty-first centuries, may provide the reader who is interested in analyzing music and its text with a broader scope of the research: Karlheinz Stockhausen, "Music and Speech," in Die Reihe 6: Speech and Music, edited by Herbert Eimert and Karlheinz Stockhausen, translated by Ruth Koenig (Bryn Mawr, PA.: Theodore Presser Company. 1964), 40-64; Wolfgang Martin Stroh, "Schoenberg's Use of Text: The Text as a Musical Control in the 14th Georgelied, op. 15," translated by Barbara Westergaard, Perspective of New Music 6/2 (1968), 35-44; David Lewin, “A Way to Schoenberg's Opus 15, Number 7," In Theory Only 6/1 (1981), 3-24; Chandler Carter, "The Rake's Progress and Stravinsky's Return: The Composer's Evolving Approach to Setting Text," Journal of the American Musicological Society 63/3 (2010), 553-640.

7. Some studies focus on the issue of pitch orthography in the works by other early twentieth-century composers. These can be found in Malcolm Gillies, "Bartók's Notation: Tonality and Modality," Tempo 145 (June 1983), 4-9; id., Notation and Tonal Structure in Bartók's Later Works (New York: Garland, 1989); id., "Pitch Notations and Tonality: Bartók," in Models of Musical Analysis: Early Twentieth-Century Music, edited by Jonathan Dunsby (Oxford and Cambridge: Blackwell Publishers, 1993), 42-55; Edward Gollin, "Aggregate Structure and Cyclic Design at the Conclusion of Bartók's Second String Quartet," in The String Quartets of Béla Bartók: Tradition and Legacy in Analytical Perspective, edited by Dániel Péter Biró and Herald Krebs (New York: Oxford University Press, 2014), 170-184; Inessa Bazayev, "Composing with Circles, Spirals, and Lines of Fifths: Harmony and Voice-Leading in the Music of Nicolai Roslavets," Ph.D. Diss. (City University of New York, 2009); id., "The Circle of Fifths in Russian Non-Tonal Music: A Case Study of Selected Works by Roslavets and Stravinsky," Dutch Journal of Music Theory 18/2 (Spring 2013), 51-68; id., "Triple Sharps, Quint Relations, and Symmetries: Orthography in the Music of Nicolai Roslavets," Music Theory Spectrum 35/1 (March 2013), 111-131; id., "The Expansion of the Concept of Mode in Twentieth-Century Russian Music Theory," Music Theory Online 20/3 (2014); George Perle, "Scriabin's Self-Analysis," Music Analysis 3/2 (July 1984), 101-122; Yi-Cheng Daniel Wu, "Scriabin's Prelude Op. 67 No. 1: Pitch Orthography, Musical Climax and Form," Music Analysis 36/3 (August 2017), 419-450.

8. Gillies, "Pitch Notations and Tonality: Bartók," 43. Using D-flat 4 (m. 20) from the last vocal phrase in Feature (6) in Example 1 as an illustration, no matter what musical context encountered, we perceive it syntactically and structurally as pc 1 , paying very little or perhaps even no attention to Webern's intention of notating

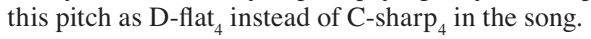




\section{Analysis of the text}

The text of Webern's song op. 12, no. 2, Die geheimnisvolle Flöte, is taken from a Chinese poem paraphrased by Hans Bethge (1907). ${ }^{9}$ His paraphrase is far from the original Chinese, for he rewrites a German translation by Hans Heilmann (1905) ${ }^{10}$ whose source come from two French translations, one by Le Marquis d'Hervey de Saint-Denys (1862) ${ }^{11}$ and the other by Judith Gautier (1862). ${ }^{12}$ Having undergone several translations through different languages, Die geheimnisvolle Flöte has been transformed into its own, unique poem, quite different from the original Chinese, whose meaning has been largely lost in Bethge's text. Although this paper focuses on the way Webern sets Bethge's poem to music, none of the current related analytical or historical literature has critically reviewed Bethge's misleading paraphrase. Thus, I feel it is necessary for this part of the paper to restore the initial meaning of the poem by translating Die geheimnisvolle Flöte directly from Chinese into English, and further compare the differences between Bethge's version and my own. Importantly, the music analysis to follow will adhere to the textual, verse structure defined in this section. The following presents the original Chinese text along with my translation. ${ }^{13}$

9. German poet (1876-1946), who published several volumes of poems, plays, and diaries. His worldwide reputation nowadays is achieved mostly through his paraphrases of a collection of the Chinese classic poetry published in an anthology Die Chinesische Flöte: Nachdichtungen Chinesischer Lyrik (1907). Both the texts of Webern's Die geheimnisvolle Flöte and Mahler's symphonic song cycle, Das Lied von der Erde, come from this anthology. See Kathryn Bailey, "Webern, Anton," in The New Grove Dictionary of Music and Musicians, edited by S. Sadie and J. Tyrrell, vol. 27 (London: Macmillan, 2001), 184; Allen Forte, "New Approaches to the Linear Analysis of Music," Journal of the American Musicological Society 41/2 (Summer 1988), 258; Julian Johnson, “The Transformation of Memory: The Vocal Works Op. 12-Op. 19 (1914-1926)," in Webern and the Transformation of Nature (Cambridge: Cambridge University Press. 1999), 256 [note no. 9]; Anne C. Shreffler, "Introduction: Webern and Lyric Expression," 4-5; Rudolph Stephan, "Zu einigen Liedern Anton Weberns," in Österreichische Gesellschaft für Musik Beiträge 1972/73: Webern-Kongress (Kassel: Bärenreiter, 1973), 135-144; Luigi Rognoni, "The Expressionism and Abstraction of Anton Webern," in The Second Vienna School: Expressionism and Dodecaphony, translated by Robert W. Mann (London: Calder, 1977), 337338; John C. Crawford and Dorothy L. Crawford, “Anton Webern," in Expressionism in Twentieth-Century Music (Bloomington and Indianapolis: Indiana University Press), 119-120. Besides Webern and Mahler, many 20th- and 21st-century composers also set poems from Bethge's anthology into songs. For instance, Toch's op. 29 (1922) sets three of Bethge's poems into chamber vocal works. The texts of the third and fourth songs from Schoenberg's op. 27 (1925) also come from the same source. The more recent text settings appear in the three orchestral songs from Penderecki's Drei Chinesische Lieder für Bariton und Orchester (2008).

10. Hans Heilmann, Chinesische Lyrik vom 12. Jahrhundert v. Chr. bis zur Gegenwart (Munich: Piper Verlag, 1905). Heilmann's version of the poem will be provided later in note no. 17.

11. Le Marquis d'Hervey de Saint-Denys, Poésies de l'époque des Thang (Paris: Amyot, éditeur des archives diplomatiques, 1862).

12. Judith Gautier, Le Livre de Jade: Poésies Traduites du Chinois (Paris: Alphonsè Lemerré, 1862). Bethge mentions all these French and German sources in his preface (Hans Bethge, Die Chinesische Flöte: Nachdichtungen Chinesischer Lyrik [Leipzig: Im Inselverlag, 1907], 110-111). For a detailed tracing of Bethge's anthology translation process from its sources, see Stephen Hefling, Mahler: Das Lied von der Erde (Cambridge: Cambridge University Press, 2000), 36-37; Laura Tunbridge, The Song Cycle: Cambridge Introductions to Music (Cambridge: Cambridge University Press, 2011), 78; Fusako Hamao, "The Sources of the Texts in Mahler's Das Lied von der Erde," 19th-Century Music 19/1 (Summer 1995), 83-95.

13. I am very grateful that my colleagues Kathleen Marien and Eugena Riehl provided valuable advice in my English translation process. 


\begin{tabular}{|l|l|}
\hline $\begin{array}{l}\text { 春夜洛城聞笛 [Title] } \\
\text { 季白 [Li Tai-Bai, 735 A.D.] }\end{array}$ & $\begin{array}{l}\text { Song of the Flute } \\
\text { Trans. by Yi-Cheng Daniel Wu }\end{array}$ \\
\hline (1) 誰家玉笛暗飛聲 & Whose flute sings this melody in the dark? \\
\hline (2) 散入春風霂洛城 & It flows through the city of Luo Yang in the spring wind. \\
\hline (3) 此夜曲中聞折柳 & Filling the night air with the farewell song “Willow Branch,” \\
\hline (4) 何人不起故園情 & Who can bear such nostalgia? \\
\hline
\end{tabular}

The poet Li Tai-Bai ${ }^{14}$ (commonly known as Li Bai; 701-762 A.D.), one of the three greatest poets in the Tang Dynasty (618-907 A.D.), ${ }^{15}$ composed the poem in 735 A.D. ${ }^{16} \mathrm{He}$ was at his best singing of love and friendship, of the delights of wine, and of the strange, majestic, and awe-inspiring aspects of nature. My English translation aims to keep the concise, clean, and simple style of Li Tai-Bai's poem, which represents the feeling of nostalgia. The following shows Bethge's version. For the sake of a more accessible discussion, I also provide Allen Forte's 1998 English translation, which is fairly close to Bethge's text.

\begin{tabular}{|l|l|}
\hline Die geheimnisvolle Flöte & The Mysterious Flute \\
Trans. by Hans Bethge (1907) & Trans. by Allen Forte (1998) \\
(2) An einem Abend, & (2) During an evening, \\
da die Blumen dufteten & as the flowers exuded fragrance \\
und alle Blätter an den Bäumen & and all the leaves on the trees, \\
(1) trug der Wind mir das Lied & (1) the wind brought me the song \\
einer entfernten Flöte zu. & of a distant flute. \\
(3) Da schnitt ich & (3) Then I cut \\
einen Weidenzweig vom Strauche, & from the tree a willow branch, \\
und mein Lied flog, & and my song flew, \\
Antwort gebend, & giving answer, \\
durch die blühende Nacht. & through the blossoming night. \\
(4) Seit jenem Abend hören, & (4) Since that evening, \\
wenn die Erde schläft, & When the earth sleeps, \\
die Vögel ein Gespräch & The birds hear a conversation \\
in ihrer Sprache. ${ }^{17}$ & in their language. \\
\hline
\end{tabular}

14. In this paper, the spelling of the name of the poet Li Tai-Bai is based on the modern Chinese Pinyin system. Bethge spells his name as Li Tai-Po.

15. The three greatest poets of Tang Dynasty are Li Tai-Bai, Wang Wei (699-761 A.D.), and Du Fu (712770 A.D.).

16. Poetry of the Tang Dynasty presents a strict form with five or seven characters in a verse, four or eight verses in a poem. A rhyme pattern falls on the last character of even verses. In the four-verse poem, the last character of the first verse can either be rhymed or not, but that of the third must not rhyme. Here the form of this poem features a four-verse structure, and each verse contains seven characters. Verses (1), (2), and (4) end with rhymed consonant "ng." In verse (1), the last character is 聲, which means "voice” and is pronounced as "sheng." The last character in verse (1) is 城, which is translated into "city" and pronounced as "cheng." 情 (ching) appears at the end of verse (4), which can be interpreted as "feeling." 
I add Arabic numbers to both Bethge and Forte's poems. Each number refers to their corresponding verse in Li Tai-Bai's poem. Bethge slightly reverses the first two verses, beginning with verse (2), which sets the scene in the season of spring (implied by the words of "flowers, fragrance, leaves, trees") and the time of the day (evening). The following verse (1) brings out the main subject "flute" and its sound heard by the poet - a "song." Next in verse (3), the paraphrase deviates from the meaning of the original Chinese. In Li Tai-Bai's version, the last two characters “折柳” clarify the name of the song heard in that spring night mentioned in his preceding verse. The literal translation of this song's name is “cutting (折) a branch from a willow tree (柳)." In my translation, to maintain the succinct and poetic style of the text, I entitle this song "Willow Branch." It is an ancient song from the Han Dynasty (226 B.C.-220 A.D.), whose text expresses sad and reluctant farewell. Bethge translates the Chinese characters literally into an action: "Then I cut from a tree a willow branch," failing to convey the implied sadness so explicit in Li Tai-Bai's poem. Moreover, the action of "cutting a willow branch" seems puzzling in relation to the rest of Bethge's verse (3), in which the poet sings another song to respond to the melody played by the flute - "and my song flew, giving answer through the blossoming night." Finally in verse (4), while Li Tai-Bai's text reaches utter despair and loneliness aroused by hearing the song "Willow Branch," Bethge's version enters a drastically different poetic realm, "the birds hear a conversation in their language."

Reading through Bethge's Die geheimnisvolle Flöte, the whole nostalgic sense is lost. In fact, most related Webern studies ${ }^{19}$ connect Bethge's text to Germanic Romanticism, associating everything, here the music in particular, with "nature." That is, the imagery of Bethge's poem interprets music - songs played by the flute and sung by the poet - as nature, a language recognized by birds as their own heard in a blossoming spring evening while the earth sleeps. It is uncertain if Webern was aware of the original meaning of Li Tai-Bai's poem (which requires more thorough research), this paper examines Webern's careful observation of the structure of Bethge's text and the way he crafts it into his song with regard to musical form and pitch orthography.

17. Here I provide Heilmann's 1905's version of the poem. Bethge's paraphrase is based on this poem. The reader can compare Bethge's version with the following text. "Eines Abends trug mir der Wind, / den Ton einer fernen Flöte zu. / Da hab ich einen Weidenzwig abgeichnitten / und mit einem Liebe geantwortet. / Geitdem hören nachts, wenn alles ichlächt, / die Bögel ein Geiprächt in ihrer Sprache."

18. Note that Forte's title is the literal translation of Bethge's German title. My translation is "Song of the Flute," which takes the last two characters “聞笛” from Li Tai-Bai’s title.

19. Luigi Rognoni, "The Expressionism and Abstraction of Anton Webern," 350; Julian Johnson, "The Transformation of Memory," 136; Allen Forte, "The New Lieder: Four Songs for Voice and Piano, Opus 12," 258-259; Stephen Hefling, Mahler: Das Lied von der Erde, 37. 


\section{Vocal part: text setting, pitch orthography, and form}

Example 2 produces the annotated score of Webern's Die geheimnisvolle Flöte. Based on the structure of the poem, it contains three parts. That is, the formal division always coincides with the break of a verse in the poem. In the following discussion, the order numbers of the four verses (2), (1), (3), (4) follow the ones presented in Bethge's poem in the last section. Part I constitutes verses (2) and (1) with only an eighth rest separating them (m. 7). Verse (3) forms Part II and Part III contains verse (4). To highlight the contrasts among the formal divisions, Webern adds two short piano interludes separating the three parts from one another with a prelude and postlude on the flanking sides of the song. ${ }^{20}$ To set the text, Webern follows the traditional style of the late 19th-century Lied, arranging the words syllabically throughout the song in order to add greater comprehension of the poem. ${ }^{21}$ Also, the constant change in meter creates a sense of "floating, metreless characteristics" 22 of the vocal line, which allows Webern's text setting to closely mimic the meters and rhythms of the spoken language. ${ }^{23}$

Webern uses word painting to portray some texts. For instance in m. 4, the descending minor seventh with the word "Abend" suggests the coming of the night; and in mm. 7-9 the soprano projects a very smooth vocal line with an almost static melodic contour that repeats only three pitches $\mathrm{D}_{4}, \mathrm{E}_{4}$, and $\mathrm{E}-\mathrm{flat}_{4},{ }^{24}$ which is likely meant to depict the breeze in the night "trug der Wind mir das Lied." ${ }^{25}$ Additionally, the limited range of the voice (from $\mathrm{C}_{4}$ to D-sharp ${ }_{5} / \mathrm{E}^{- \text {flat }_{5}}$ ) and the dynamics (from $p$ to $p p$ ) both characterize the night's serene atmosphere;

20. The two interludes and the phrasal slurs are apparent indications articulating the formal features of this song. But music of the postwar period has much forsaken these traditional apparatuses in search of a more innovative compositional interpretation of formal structure. Although these innovations prod postwar music into a new architectural platform, they, nevertheless, bring the listener/analyst a new task in appreciating the layout process of the music. Prompted by this issue, Patricia Howland ("Formal Structures in Post-Tonal Music," Music Theory Spectrum 37/1 [Spring 2015], 71-97) proposes five types of "integrated parametric structures" (IPSs) to study the formal plans, giving ways of guiding the listener/analyst in understanding the form in the works written after the Second World War.

21. Anne C. Shreffler, "Introduction: Webern and Lyric Expression," 11.

22. Ibid., 11.

23. In Example 2, beginning from m. 14 until nearly the end of the song, the musical fabric gets more complex as the texture unfolds three simultaneously distinctive melodic lines (i.e., the soprano, the top voice of the piano right hand, and the lowest voice in the piano left hand). This portrays the "stylistic trait of Webern's, which can be seen in the songs Opp. 12-15 ... [and presents] the tendency towards strict polyphonic treatment of the parts" (Walter Kolneder, "The Instrumental Miniatures," in Anton Webern: An Introduction to his Works, translated by Humphery Searle [Berkeley and Los Angeles: University of California Press 1968], 89). For a related discussion, see Richard DeLone, "Timbre and Texture in Twentieth-Century Music," in Aspects of Twentieth-Century Music, edited by Gary Wittlich (Englewood Cliffs, NJ.: Prentice-Hall, 1975), 90.

24. In this paper, the term "pitch" refers to a specific note with an assigned octave designation appearing in the musical context. The "pitch-class" is used more generally to describe a note regardless of the octave in which it occurs.

25. Contrarily, in most part of the song, the soprano constantly sings wide intervals (such as fourths, fifths, sevenths, or ninth) that feature a pointlistic style of musical texture (for instance, mm. 4-5, 12-18, and 21-24). This type of melodic handling of the voice, for Webern, carries "instrumental characteristics" and creates "an expressive tension which goes beyond the normal limits" (Walter Kolneder, "The Instrumental Miniatures," 86). 
or further relevance, the lowest note in the voice $\mathrm{C}_{4}$ is also the lowest note of the flute. The above describes some apparent features of Webern's text setting in the foreground. The following goes into a deeper investigation by proposing the way Webern uses his spellings of the twelve chromatic pitches to articulate the textual structure of Bethge's poem. To proceed even further, in the next section I will briefly show how Webern crafts his pitch notation to support Morgan's "faint suggestion of reprise" defined in Example 1, causing a seemingly through-composed form with a strong allusion to a three-part ternary architecture of ABA'.

Before my analysis, I must clarify that the theoretical spectrum of this paper requires the recognition of the following two conditions. First, we acknowledge the octave equivalence but not the enharmonic. For instance, while E-flat ${ }_{4}$ is

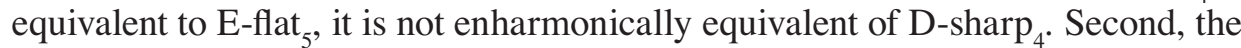
term "accidental" only refers to a single flat or a single sharp sign, not the natural one. And in this song all the raised and lowered notes always correspond to the black keys on the keyboard. Thus, cases like F-flat or B-sharp will not exist in our discussion (nor in Webern's song), because they appear on the white keys of the keyboard. Also, the extreme accidentals - i.e., double sharps or double flats - are excluded, because Webern avoids such complex notations in order to keep the readability of the score.

When I first approached this song, the entire Part III immediately caught my attention for all the accidentals in the first half of this part (mm. 19-23) appear to be flats, and those in the second half turn into sharps (mm. 23-26, see Example 3). More importantly, the division between the change of the accidentals coincides perfectly with the textual structure of verse (4). That is, the verse can be divided into two nearly equal halves (see the bottom of Example 3): the first half contains lines 1 and 2 (eight words in total) set into chromatic pitches with all flat signs, and the second half contains line 3 (seven words) set into chromatic pitches with all sharp signs. To reinforce the clarity of the shift in accidentals and the middle break of verse (4), Webern adds an eighth rest (m. 23) to divide the two halves in Part III. At the initial stage of this research, I first felt that besides articulating the textual structure of verse (4), Webern was also using accidentals to highlight the direction of the melodic contour - that is, sharps for the upward motion, and flats for the downward. Although this premise is true in the case of the second half of Part III, ${ }^{26}$ the accidentals in the first half (see the lowered pitches in the rectangle in Example 3) soon refute this reasoning, ${ }^{27}$ which ushers me to look at all these accidentals from a different perspective - pitch orthography.

26. Starting from the third beat of $\mathrm{m}$. 24, the soprano sings a gradual chromatic ascending melody from $\mathrm{E}_{4}$ to $\mathrm{B}_{4}$. The sharp signs therein create a strong visual tendency enhancing the melodic contour to rise step by step.

27. For instance, there is an octave ascent from D-flat to D-flat $_{5}$ in $\mathrm{mm}$. 20-21, and the accidentals in this ascending motion are all flat signs (D-flat $-\mathrm{E}_{4}-$ flat $_{4}-\mathrm{D}_{4}-\mathrm{D}$-flat ${ }_{5}$ ). Also, from the third beat of $\mathrm{m}$. 22 to the last note in the triplet in $\mathrm{m} .23$, the pitch contour delineates an overall ascending line. The accidentals therein are, again, flat signs (D-flat ${ }_{4}$, A-flat ${ }_{4}$, and B-flat ${ }_{4}$ ). 
EXAMPLE 2 Die geheimnisvolle Flöte; annotated score

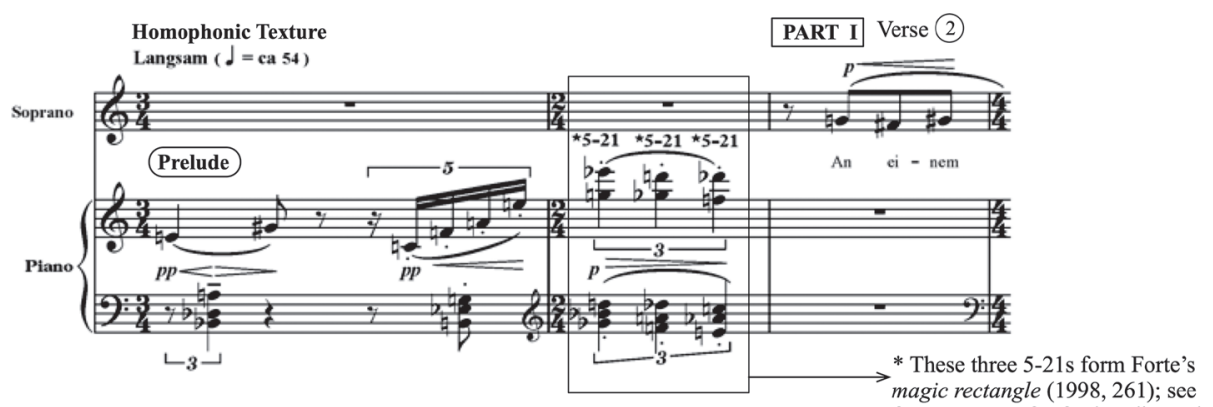
my footnote no. 5 for further discussion.
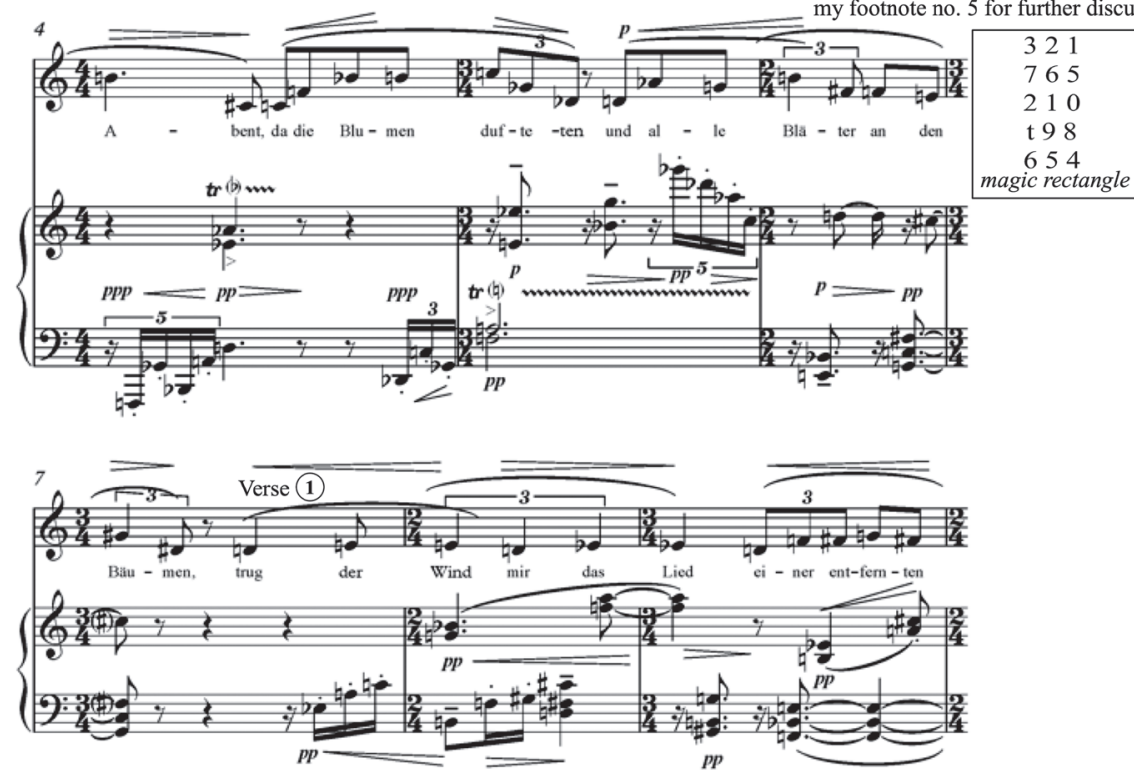

PART II

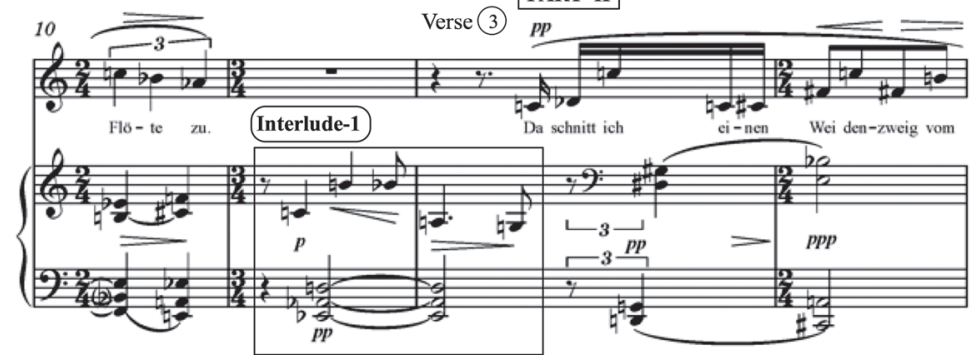


EXAMPLE 2 (continuation) Die geheimnisvolle Flöte; annotated score
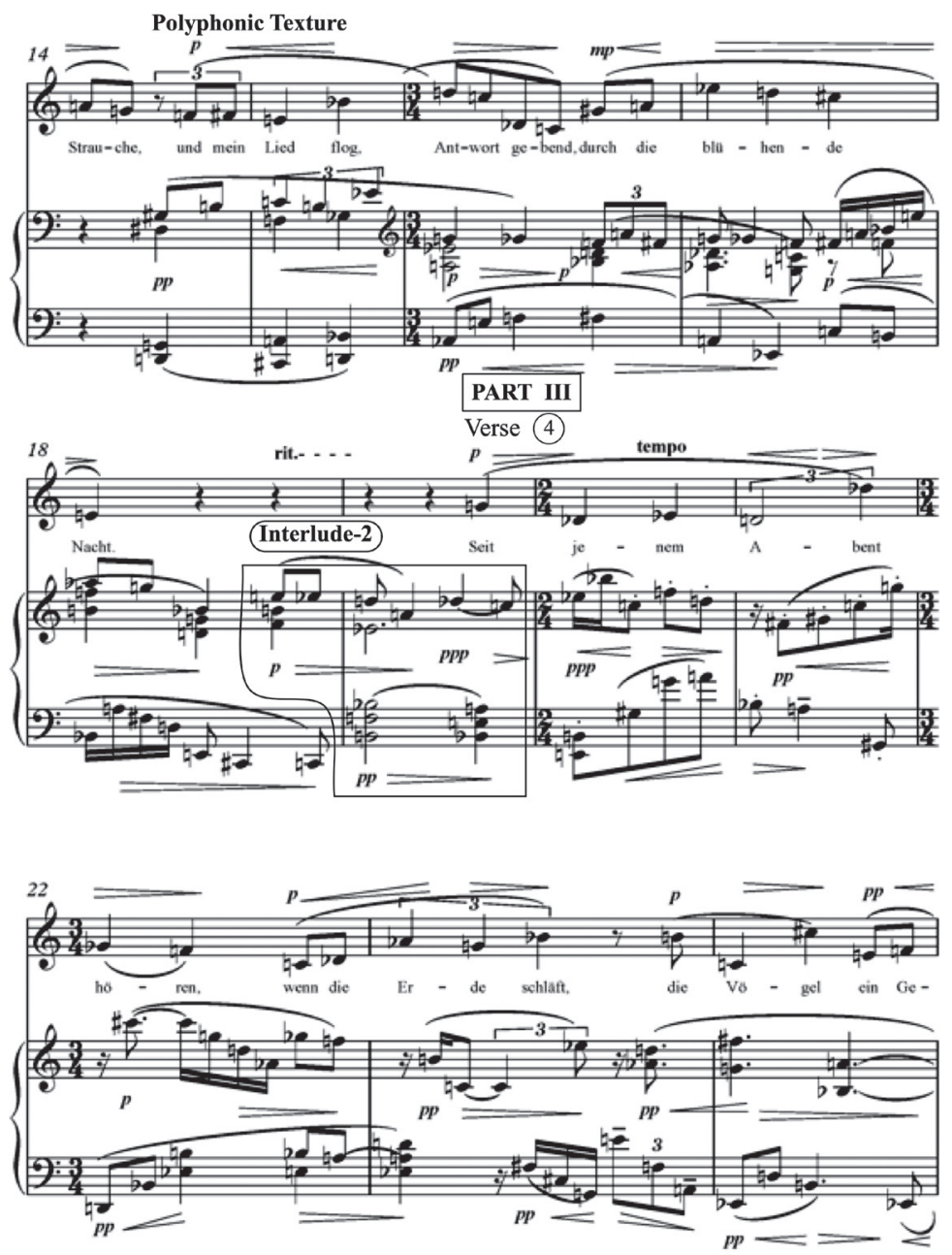

Homophonic Texture

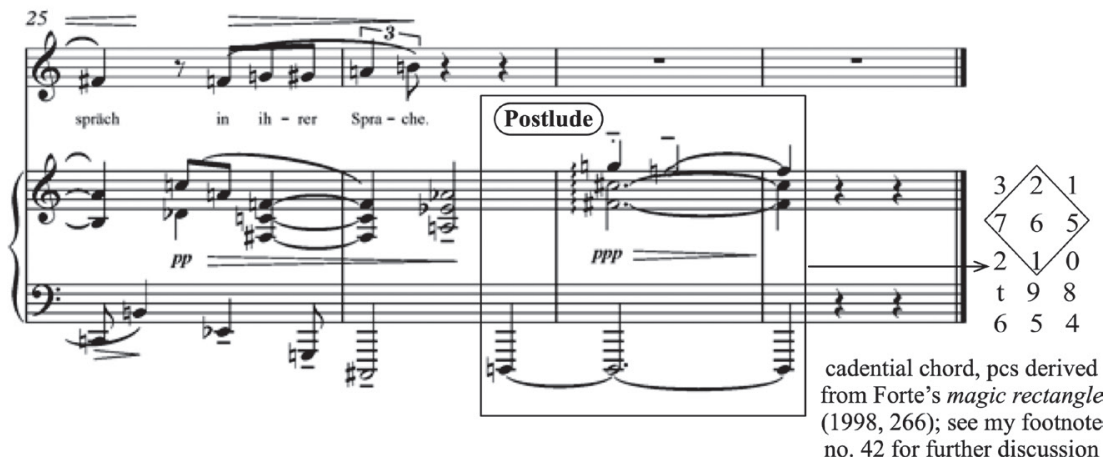


Example 3 Verse (4) (Part III, mm. 19-26) and types A-1 \& A-2 pitch orthography
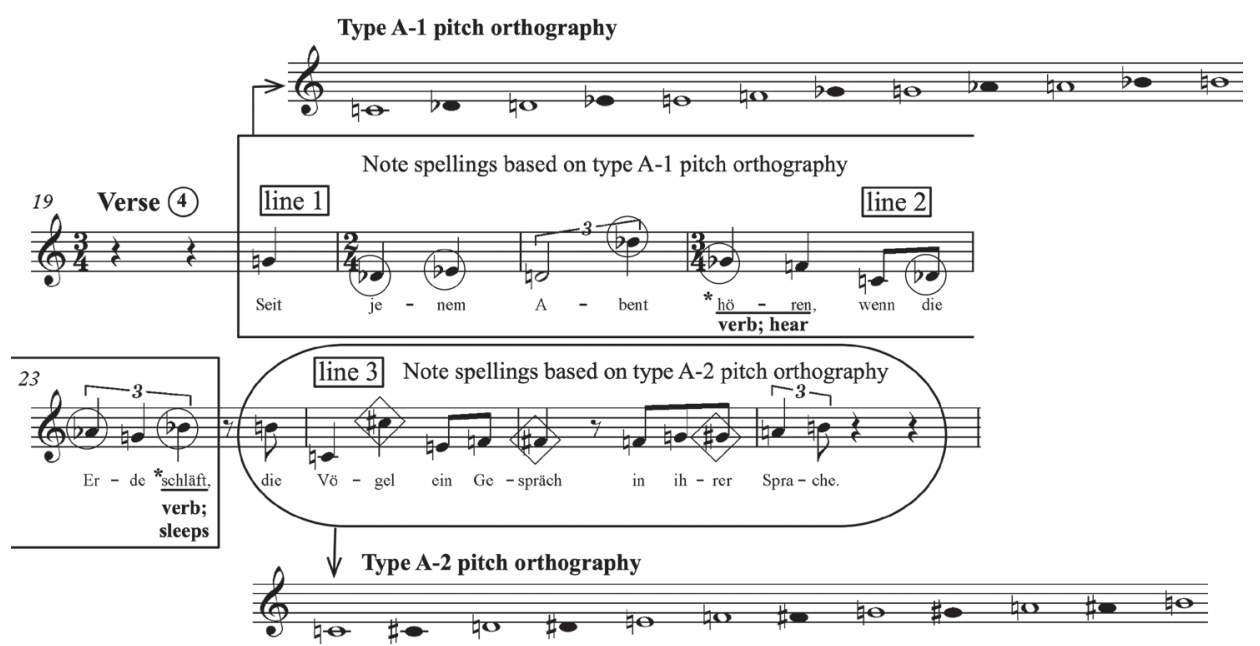

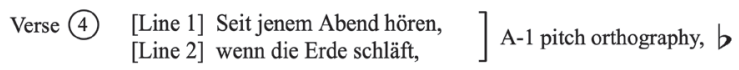

$$
\begin{aligned}
& \left.\begin{array}{l}
\text { [Line 3] die Vögel ein Gespräch } \\
\text { in ihrer Sprache. }
\end{array}\right] \text { A-2 pitch orthography, \# }
\end{aligned}
$$

I notice that the lowered pitches in the rectangle in Example 3 are pitch-classes D-flat, E-flat, G-flat, A-flat, and B-flat, which are the five black keys within an octave on the keyboard. If we consider these lowered pitches along with the seven white keys spelled as an ascending scale $<\mathrm{C}, \mathrm{D}, \mathrm{E}, \mathrm{F}, \mathrm{G}, \mathrm{A}, \mathrm{B}>$, they create a complete twelve chromatic scale. I label this scale as type A-1 pitch orthography. The pitches in the rectangle are all drawn from A-1. Following the same method, I derive another complete twelve chromatic scale labeled as type A-2 pitch orthography, which contains exclusively sharp signs. ${ }^{28}$ The pitches in the round-ended rectangle are all drawn from A-2. This theory of pitch orthography establishes a more analytically thorough, legitimate, and persuasive foundation that explains why accidentals are consistently flats or sharps at different places in Part III, which further support the textual structure of verse (4).

28. Although there are only three raised pitches F-sharp 4 , C-sharp , and G-sharp $_{4}$ on the score, the consistency of the sharp signs in mm. 24-25 provides me with a rational basis to spell the other two black keys as pitch-classes D-sharp and A-sharp.

29. Example 4 provides the analyst with a new possibility of chordal segmentation based on the system of pitch orthography. It also lends him/her a crucial reference to logically associate certain chords together for they share the same accidentals (for instance, we can relate the first, third, and fifth chordal segmentations to one another in Example 4, because they all belong to type A-2 orthography). In pitch-class set theory, some scholars also focus on the kinships among consecutive or nonconsecutive pitch-class segments that can be associated by a certain underlying attribute. The representative research of the association theory includes: Joseph Straus, "The Problem of Prolongation in Post-Tonal Music," Journal of Music Theory 31/1 (Spring 1987), 1-21; 
Example 4 Verses (2) \& (1) (Part I, mm. 3-10) and types A-1 \& A-2 pitch orthography

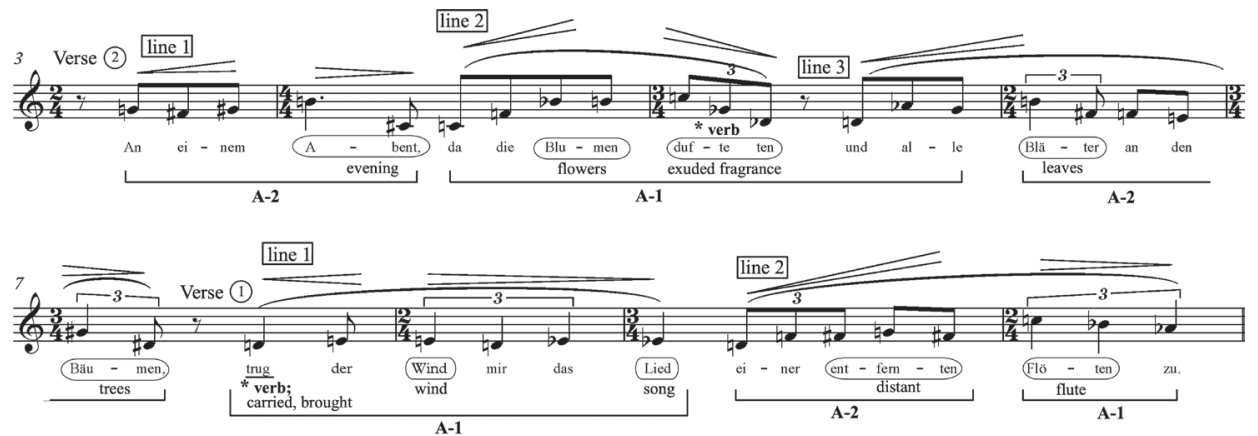

Verse (2) [Line 1] An einem Abend [evening],

[Line 2] da die Blumen [flowers] dufteten [exuded fragrance]

A-1

[Line 3] und alle Blätter [leaves] an den Bäumen [trees]

A-2

Verse (1) [Line 1] trug der Wind [wind] mir das Lied [song]

A-1

[Line 2] einer entfernten [distant] Flöte [flute] zu.

Next, let us proceed to the opening part, which contains verses (2) and (1) (Example 4). This part is also orthographically structured on the pitch spellings of A-1 and A-2. ${ }^{29}$ Different from Part III, where the accidentals articulate the largescale textual structure of the verse, in Part I the sharp and flat signs are more often used to stress the details of the text. ${ }^{30}$ In addition, they also fairly and musically reflect the change of dynamics and pitch contour. Verse (2) encompasses orthography types A-2, A-1, and back to A-2. Each type stresses one to two keywords in a line. All the keywords in this part are marked by round-ended rectangles with their corresponding English translations provided underneath. The keyword in line 1 is Abend, which indicates the time of day in Bethge's poem. Here Webern uses A-2 orthography accompanied by a complete dynamic progression of crescendo-diminuendo. While line 2 begins to describe the season of spring implied by the two words "Blumen dufteten" (flowers exuded fragrance), Webern changes

Dora Hannien, "A General Theory for Context-Sensitive Music Analysis: Applications to Four Works for Piano by Contemporary American Composers," Ph.D. Diss. (Eastman School of Music, 1996); id., "Associative Sets, Categories, and Music Analysis," Journal of Music Theory 48/2 (Fall 2004), 147-218; id., A Theory of Music Analysis: On Segmentation and Associative Organization (Rochester: University of Rochester Press, 2012); Joshua Bank Mailman, "Schoenberg's Chordal Experiment Revealed through Representational Hierarchy Association (RHA), Contour Motives, and Binary State," Music Theory Spectrum 37/2 (Fall 2015), $224-252$.

30. With that said, even though Webern still uses different types of accidentals to articulate the textual structure of the poem in verses (2) and (1) (such as the beginning of a new line or a new verse), what makes the pitch orthography so unique in Part I is that here in Example 4 the change from types A-1 to A-2 or vice versa also stresses the details - some keywords - in each line. 
the pitch spellings to A-1. Although A-1 is extended to the beginning of line 3 because of the flat sign on the second to the last eighth note in $\mathrm{m}$. 5, once the text brings up "Blätter" and "Bäume" (another two signifiers - leaves and trees representing the season of spring), not only does Webern switch his notations to sharp signs, melodically he also sets "Blätter" on the highest point of line $3\left(\mathrm{~B}_{4}\right.$ at m. 6) supported by the loudest part of the crescendo mark.

Webern changes his pitch spellings again to A-1 while verse (1) comes in after the eighth rest in $\mathrm{m}$. 7. A-1 spans the entire line 1 of this verse accompanied by a complete dynamic progression of crescendo-diminuendo, which is unlike line 1 in verse (2). The entrance of line 2 is also marked by the change of pitch orthography to type A-2. Note that Webern changes his accidentals again from sharps to flats in the same line when the text introduces the main subject of this poem - Flöte. To best accentuate this word, Webern sets "Flöte" on the peak of the melodic contour in verse (1). Also, I regard this peak as the musical climax in the entire part I for not only is $\mathrm{C}_{5}$ here in $\mathrm{m}$. 10 supported by the loudest part in the dynamic process of crescendo-diminuendo ( $\mathrm{mm} .9-10)$, it also rhythmically spans a longer duration than the previous $\mathrm{C}_{5}$ in $\mathrm{m} .5 .^{31}$

Part II contains verse (3), whose four lines are articulated by their phrasal slurs in the music (Example 5). My findings suggest that Webern changes his orthographical system in this middle part of the song. If we look at the two boxes marked by $x$ and $y$ in Example 5, Webern drastically switches his accidentals between sharps and flats. For instance in box $y$, Webern sets the word "blühende" (blossoming) on one flat ("blü-" - the first syllable) and one sharp ("-de" - last syllable). This kind of sudden change of accidentals within one single word occurs neither in Part I nor in Part III. Similarly in box $x$, the texts "und mein Lied" would likely to form type A-2 pitch orthography with a sharp sign set on "mein." The following word "flog" is set on a flat sign, which would require the change of pitch spelling to type A-1. However, labeling a brief appearance of one flat sign as a new type of pitch orthography does not seem to be analytically persuasive. ${ }^{32}$ These two issues motivate me to propose that Webern has a different pitch spelling system to notate his twelve chromatic pitches in Part II.

The accidentalized pitch-classes in this part are D-flat, E-flat, B-flat, C-sharp, F-sharp, and G-sharp. Without considering pitch-class D-flat, we can form a new complete chromatic scale whose members are related by a sequence of ascending perfect fifths starting from pitch-class E-flat (see the bottom of Example 5).

31. I must point out that although most of the time Webern's accidentals do not portray the direction of a pitch contour, those in line 2 in verse (1) (mm. 9-10), however, are exceptions. They beautifully complement the shape of a melody in this song. While the first half of line 2 (the last two beats in $\mathrm{m}$. 9) projects a chromatic ascent with sharp signs intensifying the rising motion, the second half projects a descending slop with flat signs enhancing the downward motion.

32. The reader might argue that type A-1 on the text flog can be extended to cover the next line in this verse with the text "Antwort gebend" set on the lowered pitch D-flat ${ }_{4}$ (line 3, m. 16), but the issue still remains once we reach to the text "blühende" in $\mathrm{m}$. 17 with a sudden change of accidentals. 
ExAmple 5 Verse (3) (mm. 12-18) and type B pitch orthography
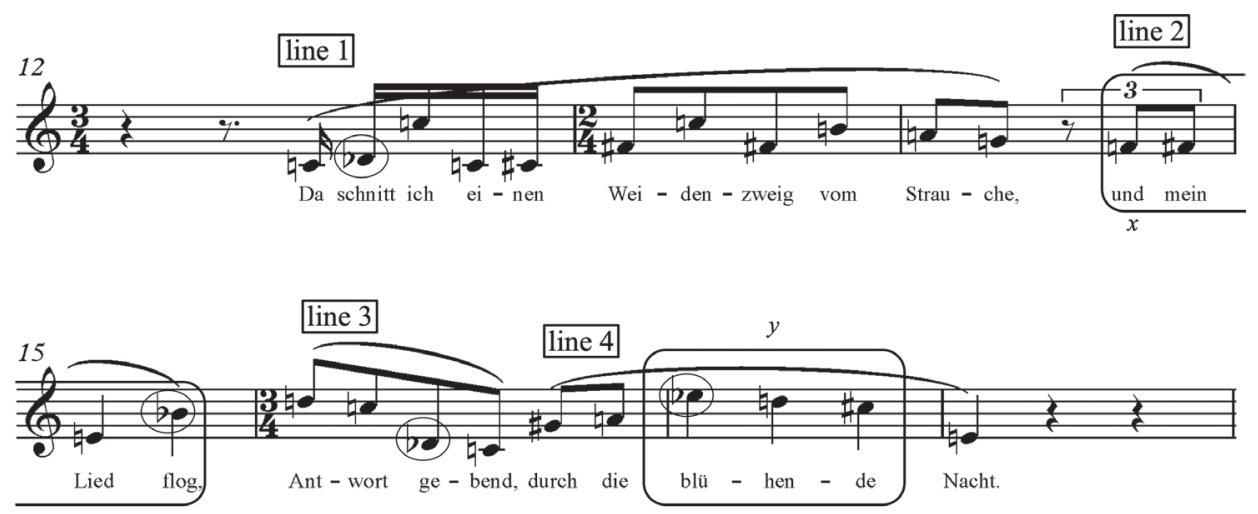

$\mathrm{D}^{b}$

[Line 1] Da schnitt* [cut] ich einen Weidenzweig vom Strauche,

$\mathrm{B}^{b}$

Verse (3) [Line 2] und mein Lied flog** [flew], $\mathrm{D}^{b}$

[Line 3] Antwort gebend*** [giving],

[Line 4] durch die blühende Nacht.
* schnitt [cut], past tense; verb root schneiden

** flog [flew], past tense; verb root fliegen

*** gebend [giving], progressive form, verb root geben

(D)

Type $B$ pitch orthography: $\mathbf{E}^{b} \rightarrow \mathbf{B}^{b} \rightarrow \mathbf{F} \rightarrow \mathbf{C} \rightarrow \mathbf{G} \rightarrow \mathbf{D} \rightarrow \mathbf{A} \rightarrow \mathbf{E} \rightarrow \mathbf{B} \rightarrow \mathbf{F}^{\sharp} \rightarrow \mathbf{C}^{\sharp} \rightarrow \mathbf{G}^{\sharp}$

ascending perfect 5 th-related

I assign this new scale type B pitch orthography. ${ }^{33}$ Then, the pitches in Part II

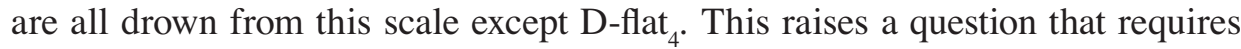
a thorough investigation: why does Webern notate pitch-class D-flat not C-sharp, which is a member of type B pitch orthography? We may well suspect that it is an orthographical mistake, for Webern misspells this pitch and we should correct

33. In fact, similar to type $B$, we can also arrange the pitch-classes in types $A-1 / 2$ by following the circle of fifths - A-1 <G-flat, D-flat, A-flat, E-flat, B-flat, F, C, G, D, A, E, B > and A-2 <F, C, G, D, A, E, B, F-sharp, C-sharp, G-sharp, D-sharp, A-sharp>. I decided to spell types A-1 and A-2 as both the ascending chromatic scales is because I want to use the most compact, economic space to organize all the pitch elements while still keeping the accidental consistency. And the most compact space would be an octave. Also, different pitch organizations can better accentuate the dissimilarity between types A-1/2 and B - ascending chromatic scales versus circle of fifths.

Moreover, the reader can regard types A-1, A-2, and B pitch orthography loosely as what most theorists term referential collections, see Richard Bass, "Models of Octatonic and Whole-Tone Interaction: George Crumb and His Predecessors," Journal of Music Theory 38/2 (Autumn 1994), 155-186; Joseph Auner, "In Schoenberg's Workshop: Aggregates and Referential Collections in 'Die glückliche Hand', Music Theory Spectrum 18/1 (Spring 1996), 77-105; Robert Cook, "Crumb's Apparition and Emerson's Compensation," Music Theory Spectrum 34/2 (Fall 2012), 1-25; Edward Pearsall, Twentieth-Century Music Theory and Practice (New York: Routledge, 2012). However, unlike the conventional sense that indicates a large pitch-class collection from which a subset may spring, in this paper types A-1, A-2, and B represent the orthographical sources to which a discrete segmentation in the vocal line orients. 
it into C-sharp ${ }_{4}{ }^{34}$ But D-flat ${ }_{4}$ occurs twice in Part II (one in m. 12 and the other in m. 16), ${ }^{35}$ and the repetition of this pitch marks its structural importance, which appears more likely as an "intentional notation" rather than an "orthographical mistake." So how do we explain the existence of this pitch?

Through my investigation, I find that Webern consistently uses flat accidentals to set his verbs. There are three verbs in verse (4): "schnitt" (past tense; cut) in line 1; "flog" (past tense; flew) in line 2; and "gebend" (progressive form; giving) in line 3. While "schnitt" and the first syllable of "gebend" are both set on D-flat ${ }_{4}$, "flog" is set on B-flat ${ }_{4}$. Importantly, this observation will become more analytically appealing if we examine how Webern sets the remaining verbs in this song. There are four more verbs in the poem, ${ }^{36}$ and three of them are also set on flattened pitches - "hören" (hear, Example 3; on G-flat ${ }_{4}$ at m. 22), "schläft" (sleeps, Example 3; on B-flat ${ }_{4}$ at m. 23), "dufteten" (exuded fragrance, Example 4; on G-flat ${ }_{4}$ and

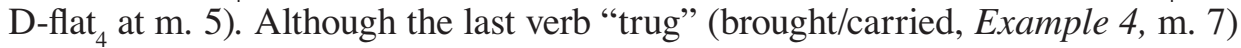
is not set on a flattened pitch, it, nevertheless, appears within A-1 type pitch orthography comprised of flat accidentals. This observation lends us an analytically convincing ground to propose the following conclusion: Webern's notation of the two D-flats instead of C-sharps in Part II is for his consistent verbal text setting on the lowered pitches throughout the vocal line in Die geheimnisvolle Flöte.

Example 6 summarizes the discussion up to this point. Due to the lack of the apparent repetitions of themes in music and verses in the poem as well as the two types of texture from homophony (mm. 1-14) to polyphony (mm. 14-26; see Example 2), ${ }^{37}$ the whole song sounds like a through-composed on the surface. But in Example 1 we find that the beginning of Part III (mm. 19-21) projects six gestures that recapture the features of the opening vocal phrase, creating Morgan's "faint suggestions of reprise." This compositional design essentially hints the song being reminiscent of a more typical ternary architectural platform of ABA'. Besides these six common features, the accidental materials in Part I - types A-1 and A-2 pitch orthography - reappear in Part III, while those in Part II are set on a footing of a different note spelling system. ${ }^{38}$ This further strengthens the underlying formal outline of ABA'. The solid arrow in Example 6 demonstrates another cru-

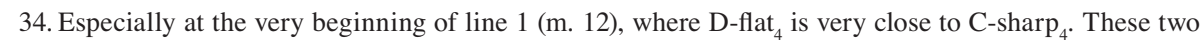
pitches appear within the same beat, and each of which spans the shortest duration of a sixteenth note in the entire vocal line. If Webern were to correct his pitch spelling from D-flat ${ }_{4}$ to C-sharp ${ }_{4}$, this four-sixteenth-note figure would be more orthographically consistent.

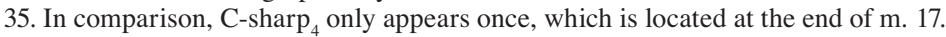

36. They are all highlighted by asterisk marks in Examples 3-4.

37. Although the homophony returns at the very end of the song, it only spans a very short period of time (mm. 25-28). The texture in the second half of the song, broadly speaking, projects a complex polyphonic fabric after $\mathrm{m}$. 14. Thus, texturally, there is an overall flow from homophony to polyphony that underlines the through-composed formal scheme.

38. In Example 1, feature (6) points out the accidentals are inversionally related at the beginning of Parts I and III. The cause of this feature is because the former is set on A-2 pitch orthography with all flat signs and the latter is on A-1 with all sharps. 
EXAMPLE 6 The formal allusion of the ternary structure ABA'

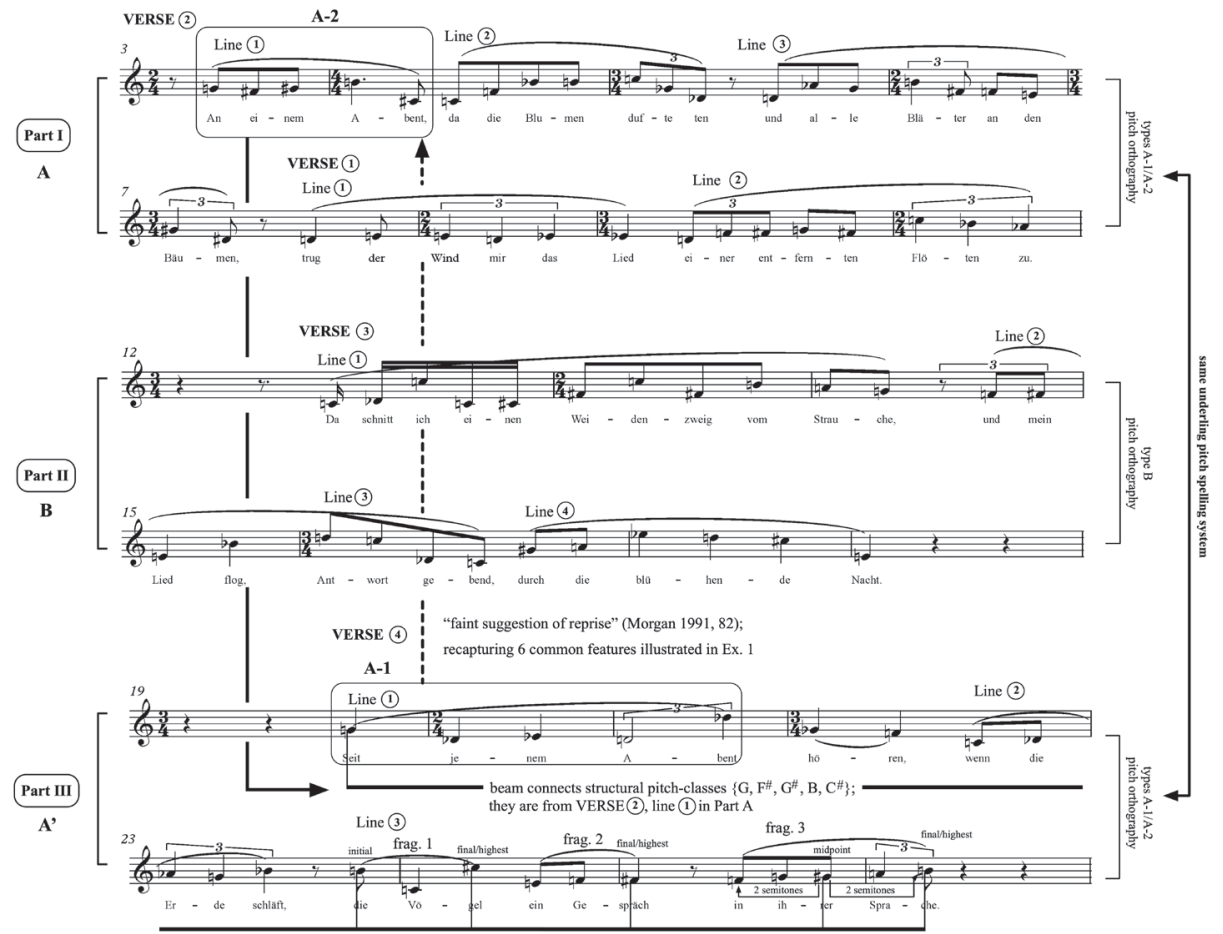

cial form-defining feature that reinforces this ternary schematic reading. Over the course of the verse (4) in Part A', all the pitch-classes in the opening vocal phrase (verse [2] line 1) in Part A recur, strategically placed at the structural locations as the initial, final/highest, or midpoint within their corresponding verse lines (line 3 subsumes three brief fragments, each articulated by a slur). Example 6 uses a beam to connect these recurrent pitch-classes in Part A'. Also, besides pitch-class C-sharp, the remaining G, F-sharp, G-sharp, B retain the same registers as those in Part A. The next section studies the pitch orthography in the piano part, examining how the piano supports the formal outline of $\mathrm{ABA}^{\prime}$ scheme.

\section{Piano part: The reinforcement of the ternary scheme}

Following the previous formal definition, this section uses A, B, and A' to represent the three formal parts. Example 7 incorporates the vocal sections of verses (2), (1), (3), and (4) with the four piano solo passages, showing a larger-scale ternary formal outline. Parts $\mathrm{A}$ and $\mathrm{A}^{\prime}$ unfold an identical threefold schematic design a brief two-measured piano solo passage framing both sides of a seven-measured 
EXAMPLE 7 Ternary formal outline with the inclusion of the four piano solo parts

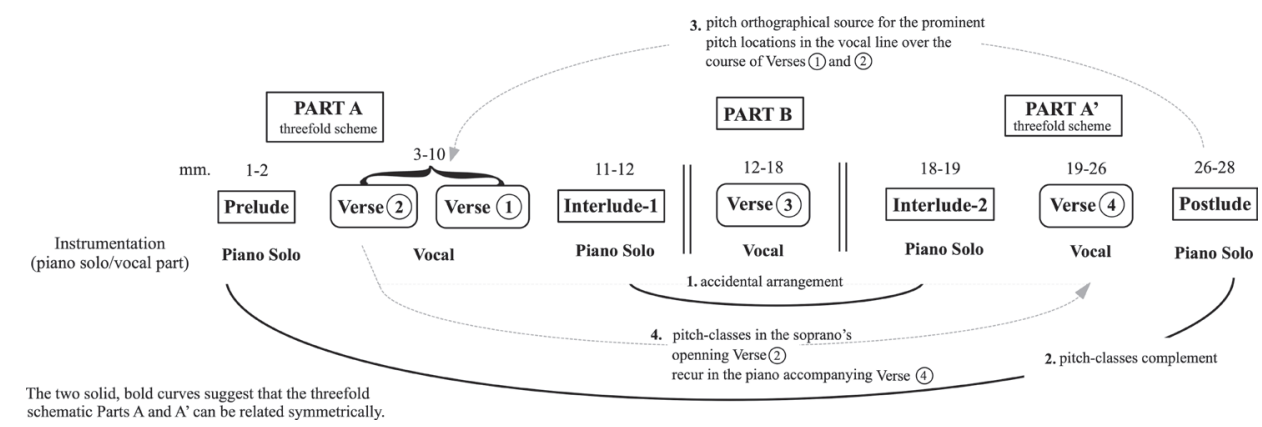

vocal section. Four different orthographical situations adhere to both threefold schematic Parts A and A'. These situations demonstrate the way Webern craftily consolidates the formal similarity and the formal reprise process crossing the border between the two flanking parts: (1) the arrangement of the accidentals between Interludes 1 and 2, (2) the complementary pitch-class collections between Prelude and Postlude, (3) the same pitch-class collections between the piano postlude and the vocal line in Part A, and (4) the pitch-classes in the opening vocal phrase in Part A recur in the piano accompaniment in Part A'. The following explains these four situations in detail.

The two interludes share several common formal features (Example 8). They project a similar homophonic fabric set on the platform of note-spelling type A-1. Within this fabric, a principal melody is articulated by the dynamics of $p$, which is supported by one to two trichords accompaniment with a weaker dynamics of pp. Moreover, this textural similarity will be even more analytically appealing if we take into account the arrangements of the accidentals. Both melodies unfold a non-retrogradable accidental pattern narrated by flat and natural ${ }^{39}$ and the accompanying trichords swap their flats with naturals and vice versa crossing the two interludes. This flat-natural swap also involves an interval exchange between a perfect fourth and a tritone. Based on the above observations, the two interludes are intimately bound together, relating the end of Part A to the beginning of Part A'.

Example 9 presents the analysis of pitch orthography in the piano accompaniment in Part A. Except for G-sharp 4 in the prelude (m. 1), every pitch has a clear, derivative orthographical meaning, because it can be traced back to one of the three note-spelling types A-1, A-2, and B proposed earlier in the previous section. If we disregard the G-sharp 4 in $\mathrm{m}$. 1, the prelude abounds with five lowered pitch-classes D-flat, E-flat, G-flat, A-flat, B-flat, suggesting a pure orthographical spectrum of type A-1. But the appearance of the G-sharp 4 urges a deeper look at

39. "Non-retrogradable" in a sense that reading the accidentals forward will be exactly the same as reading them backward. 
ExAmpLe 8 Similarities between Interludes 1 and 2

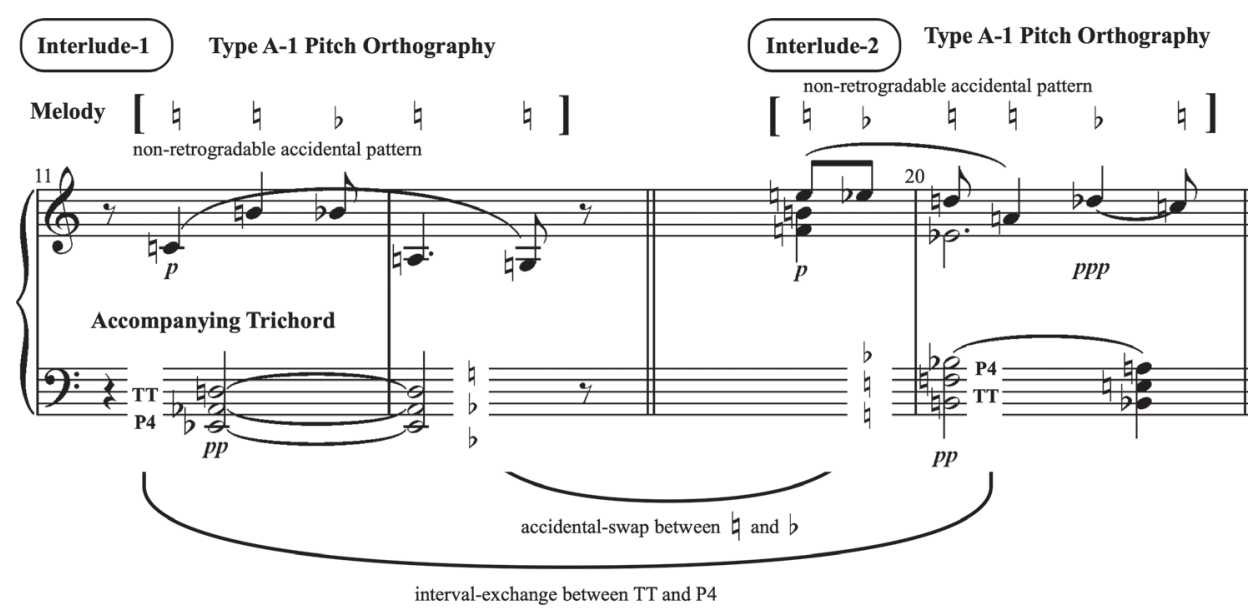

the prelude in terms of its orthographic design. To include the only raised pitchclass G-sharp within the environment saturated with the five lowered pitch-classes, I combine type A-1 \{C, D-flat, D-natural, E-flat, E-natural, F, G-flat, G-natural, A-flat, A-natural, B-flat, B-natural $\}$ with type B $\{$ E-flat, B-flat, F, C, G, D, A, E, F-sharp, C-sharp, G-sharp\}. This is the most concise hybrid-form that can encompass all the accidentalized pitch-classes throughout $\mathrm{mm}$. 1-2. I use a new presentation to represent this hybrid version of $A-1+B$, in which all the pitch-classes are systemically arranged by the circle of fifth and the duplicated pitch-classes are eliminated: \{G-flat, D-flat, A-flat, E-flat, B-flat, F-natural, C-natural, G-natural, D-natural, A-natural, E-natural, F-sharp, C-sharp, G-sharp\}. I call this hybrid version type $\mathrm{C}$.

However, the questions still remain: why does Webern notate that pitch-class in $\mathrm{m}$. 1 as G-sharp ${ }_{4}$ not A-flat ${ }_{4}$ ? Would not it be orthographically more coherent if he were to spell that pitch as A-flat ${ }_{4}$, so the entire prelude could stand on a purer notational ground of type A-1? Moreover, without the occurrences of another two raised pitch-classes F-sharp and C-sharp, the proposal of the new hybrid type $\mathrm{C}$ may seem to be less theoretically persuasive. Hence, to make type $\mathrm{C}$ a more convincing orthographical source candidate for the prelude, the following question also begs for an answer: where in the form does Webern locate these two absent pitch-classes F-sharp and C-sharp, ones that complement the accidentalized pitch-classes in the opening piano passage?

To respond to the questions raised above, we must consider the pitch orthography in the postlude in Part $\mathrm{A}^{\prime}$ (Example 10). On the surface, the two sharped pitches in m. 27 may indicate that the postlude is written based on the note-spelling type A-2, whose accidentalized pitch-classes are all marked with sharp signs. Strikingly, however, these two sharped pitches are pitch-classes F-sharp and 
EXAMPLE 9 Pitch orthography analysis of Part A, mm. 1-12

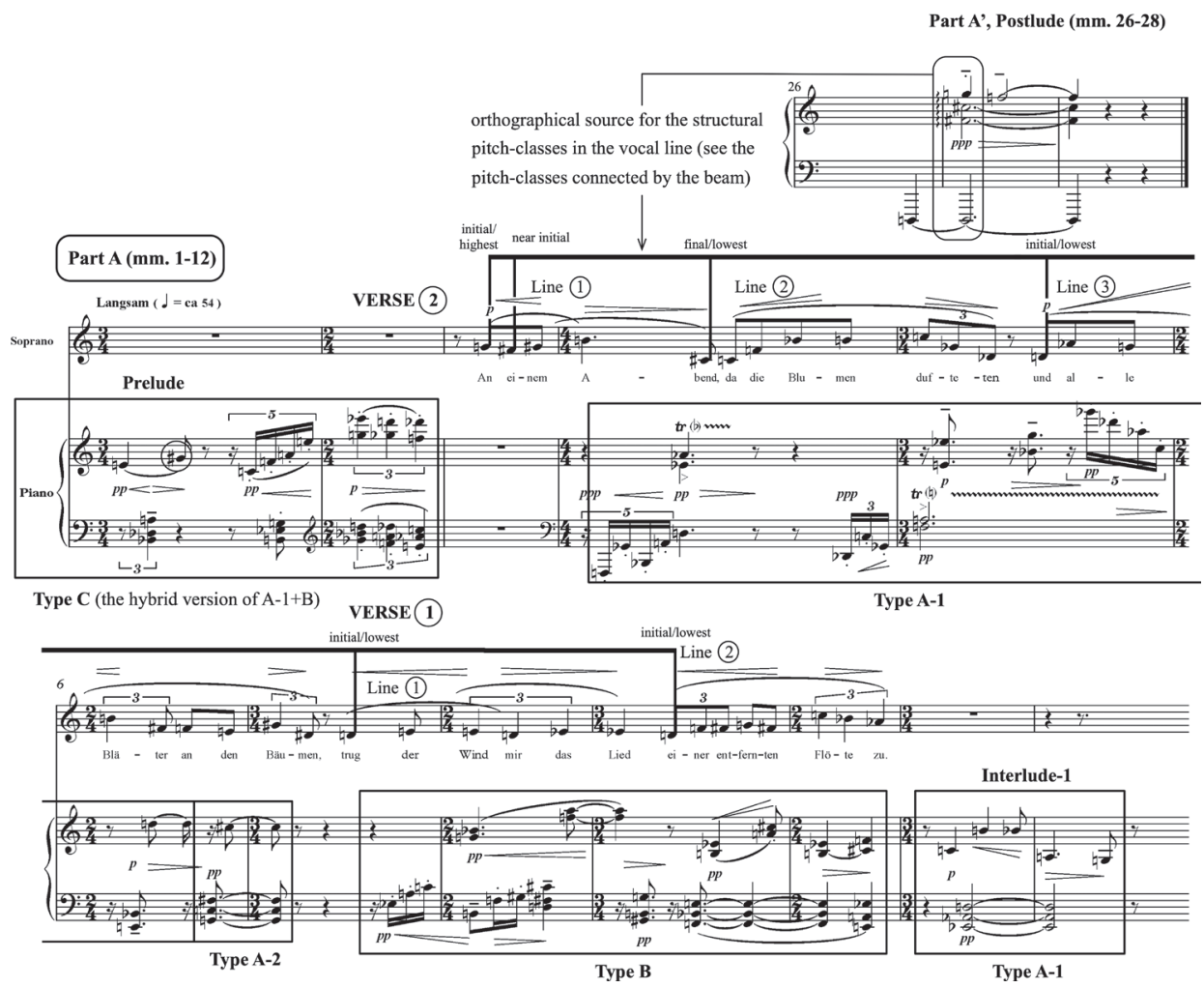

C-sharp, ones that are missing back in the prelude. In addition, considering the formal location of the postlude, it situates at the end of Part A', symmetrically opposite to the position of the prelude at the beginning of Part A. This geographical analysis of the G-sharp 4 and F-sharp $/$ C-sharp 5 reveals a magnetism bound by the complementary relationship of the note-spelling type $\mathrm{C}$ between the prelude and postlude. (Accordingly, later in Example 11 I mark the note-spelling type for the postlude as type $\mathrm{C}$ instead of type A-2.) There is an additional geographic coherence among these three pitch-classes - they all appear at the beginning of the prelude/postlude. Importantly, this binding notational relationship between the prelude and postlude, together with another binding notational relationship between Interludes 1 and 2 presented earlier in Example 8, makes the threefold schematic Parts A and A' symmetrical (see the two solid, bold curves back in Example 7).

Besides the prelude and postlude, the hybrid type $\mathrm{C}$ is also the orthographical source for the pitches accompanying the vocal line in Part A' (Example 11). At first glance, the three raised pitch-classes F-sharp, C-sharp, and G-sharp may seem to fleetingly and freely float on the surface primarily woven by the five lowered pitch-classes G-flat, D-flat, B-flat, E-flat, B-flat appearing with frequen- 
EXAMPLE 10 The complement relationship of the accidentalized pitch-classes between Prelude and Postlude

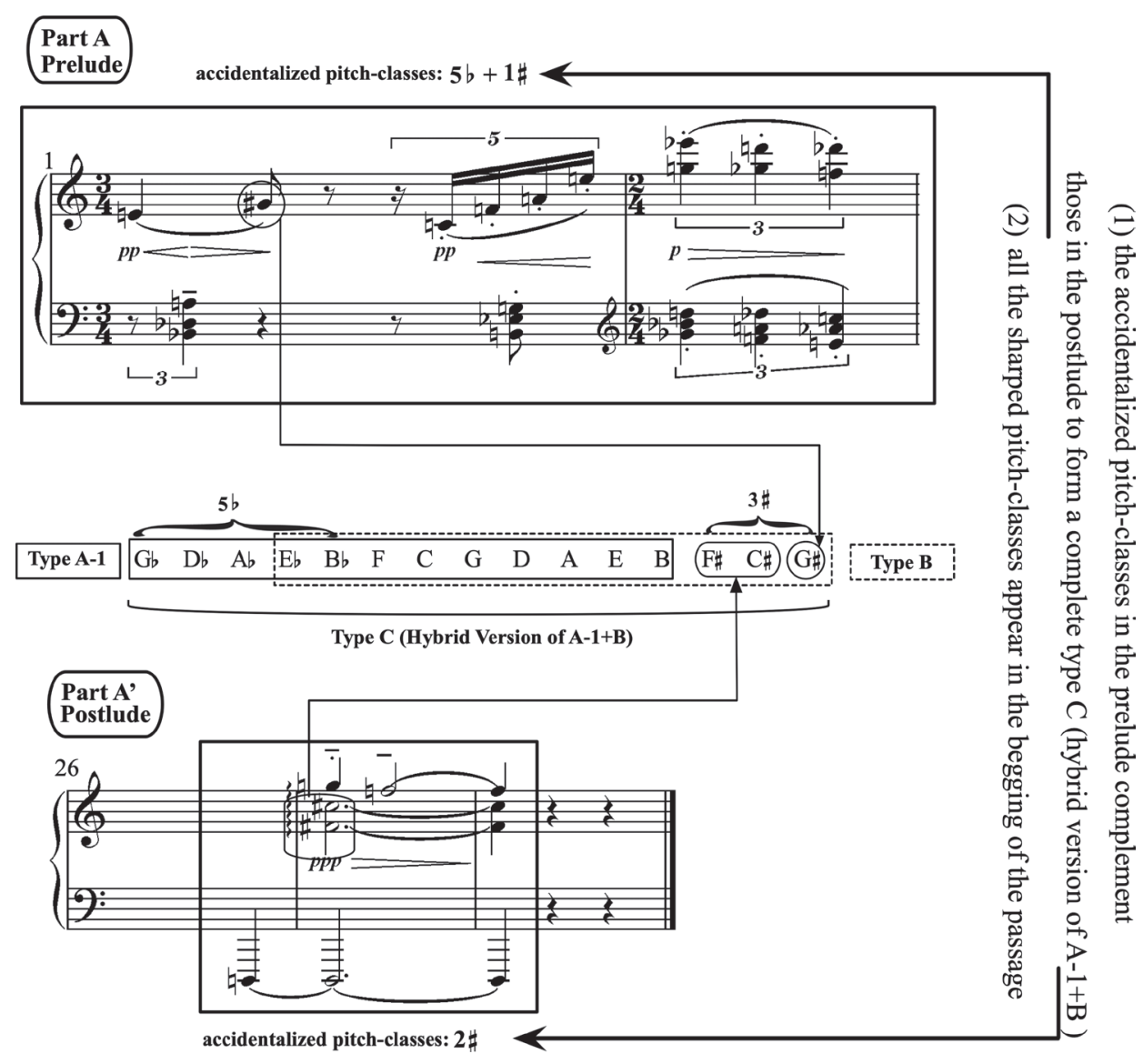

cy throughout mm. 21-26. However, a closer look at this piano accompaniment reveals two profound ways demonstrating how Webern carefully arranges most of these three raised pitch-classes to articulate the relationships among different formal parts.

The first is another example of Morgan's "faint suggestion of reprise." While the soprano sings the word "Abend" in $\mathrm{m}$. 22, the pianist's right hand plays an ascending melody to accompany that text, which is composed of pitches F-sharp ${ }_{4}$,

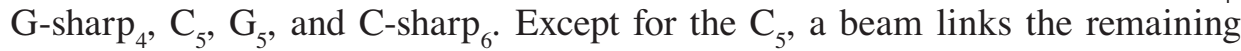
pitches. Importantly, these beamed pitches are the pitch-classes that Webern also uses to set the opening vocal phrase in Part A, which contains the same text "Abend" as well. Although the $\mathrm{B}_{4}$ in the opening vocal phrase in Part A and the $\mathrm{C}_{5}$ in the piano right-hand melody in Part A' are two different pitches, they are, nevertheless, only one semitone away from each other. In this context, the 
Example 11 Pitch orthography analysis of Part A', mm. 19-28
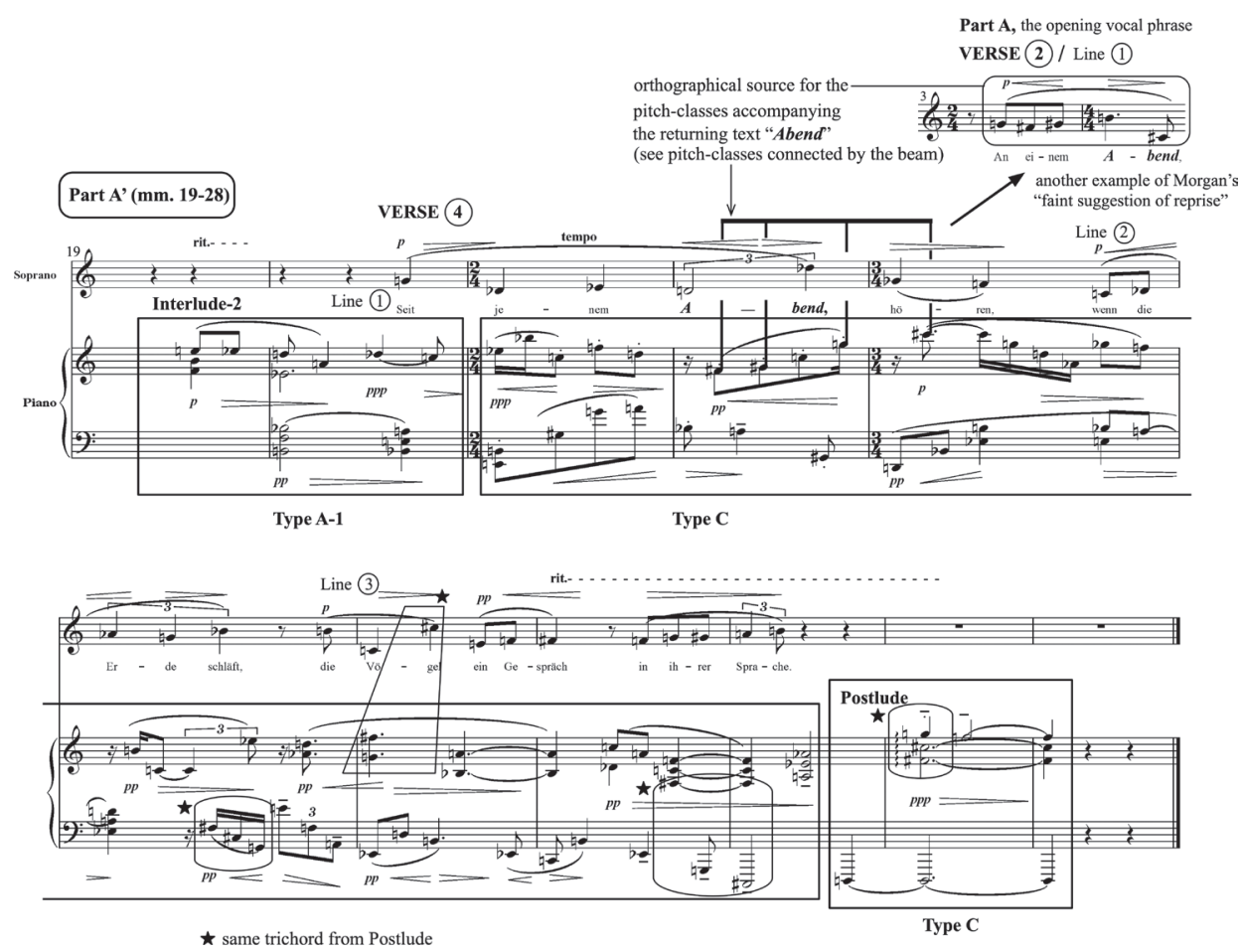

formal reprise in Part $\mathrm{A}^{\prime}$ is achieved through recycling the same pitch-classes that are used to set for the vocal phrase. A second instance of the usage of the raised pitch-classes is marked by a star sign in Example 11. Toward the middle and the end of vocal phrase verse (4), Webern writes three $\{\mathrm{C}$-sharp, F-sharp, $\mathrm{G}$-trichords: two take places in the piano accompaniment and one crosses from the vocal part to the piano accompaniment. This $\{\mathrm{C}$-sharp, F-sharp, G $\}$-trichord is emphasized again at the prominent position on the downbeat of $\mathrm{m} .27$ in the postlude, crossing over and subsiding the formal boundary from the vocal part to the piano solo passage within Part A'.

Finally, let us consider again this $\{\mathrm{C}$-sharp, F-sharp, $\mathrm{G}\}$-trichord along with its accompanying bass note, pitch-class D, on the downbeat of m. 27 (see the grand staff on the upper right corner in Example 9). All these four pitch-classes are the orthographical sources for Webern to write the structural pitches over the course of vocal line in Part A. They are strategically placed at the prominently exposed boundary positions (initial, final, highest, and lowest) within a particular verse line. Also, among these four pitch-classes, pitch-class D - the lowest note back in the postlude - occurs three times in a row starting from verse (2) line 3 (m. 5), to verse (1) line 1 (m. 7), and then to verse (1) line 2 (m. 9). It always occupies 
ExAmPLe 12 Pitch orthography analysis of Part B, mm. 13-18

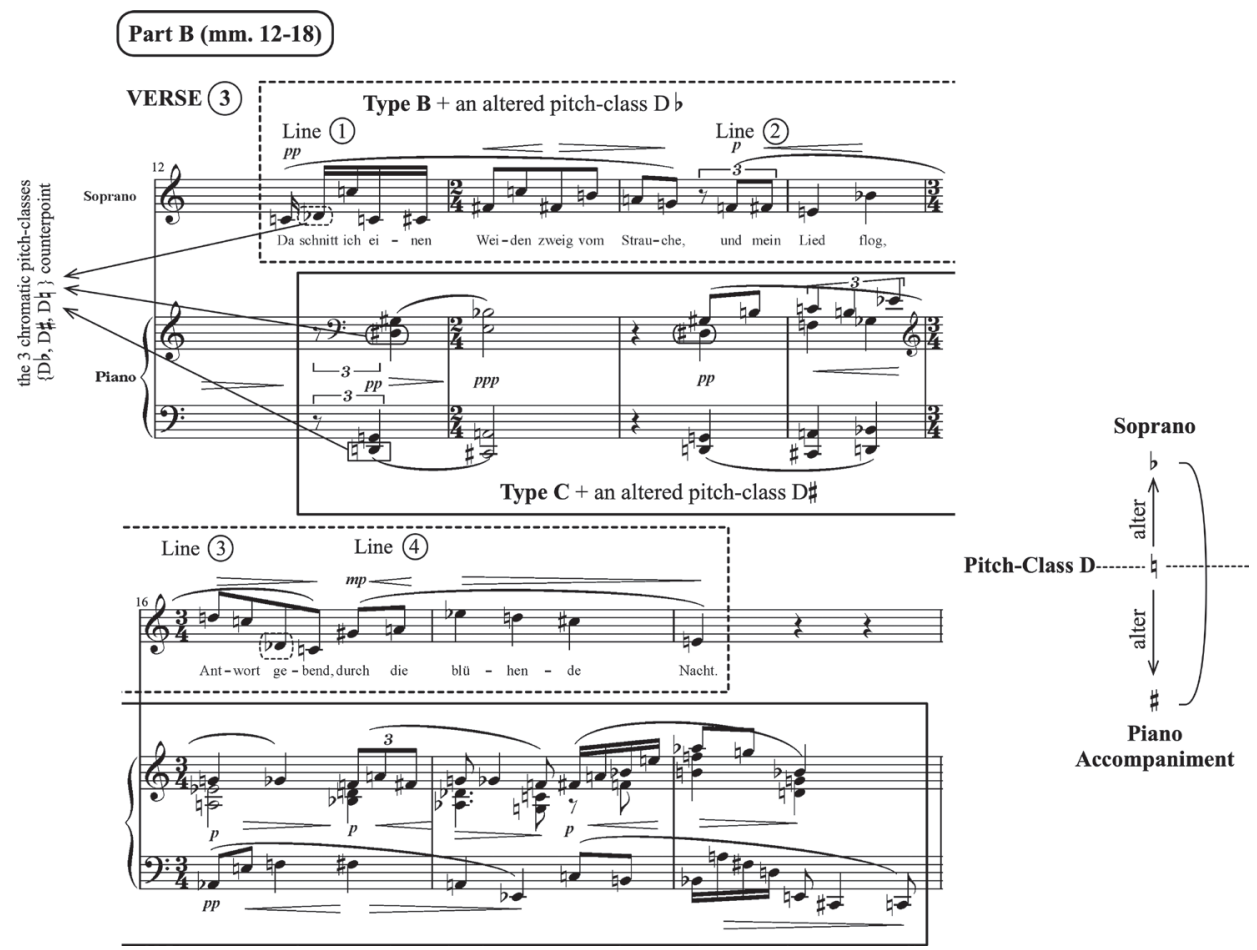

the initial/lowest point within these three verse lines. Furthermore, the vocal line begins with pitch-class $\mathrm{G}$ (m. 3), which is the boundary, highest pitch back in the postlude as well. This coherent pitch-class composition lends the song one more crucial form-defining feature that reinforces the relationship between the flanking parts of A and A'.

Example 12 presents the orthographic analysis of Part B. This part stands out and distinguishes itself from its neighboring parts in its special treatment of the pitch-class D. As pointed out in the previous section, the orthographical source for the vocal phrase verse (3) is type B with an additional altered pitch-class D to D-flat to articulate the verb in the text. The orthographical source for the piano accompaniment is type C. Similarly, Webern also alters the pitch-class D to D-sharp, whose accidental is inversionally related to D-flat around D-natural. Each altered pitch-class equally takes places twice in the first half of Part B. Note that Webern introduces these two altered D-flat and D-sharp along with D-natural right at the beginning of Part B at $\mathrm{m}$. 12, creating a three-chromatic-pitch-class counterpoint crossing three different voices. This three-voice counterpoint announces the arrival of a new Part B with the clearly pronounced handling of the pitch-class D. 
Although this paper does not go into detail about the historical background of Webern's intents to design a work registering pitch accidentals (which is worth further study in the future), it nevertheless presents a no-less-convincing analysis of his Die geheimnisvolle Flöte, providing the performer, listener, and analyst with instructive guidance to comprehend the superficial texture that is both chromatically and enharmonically diverse while limiting pitch-spelling variety. It also brings to the fore a revealing conclusion about how the significance of pitch orthography in the text setting and the three-part formal design of this song. ${ }^{40}$ Additionally, it is important to clarify that the present paper is not against the traditional analyses of this song based on the set-class theory, ${ }^{41}$ which recognizes the enharmonic pitches as representing the same pitch-class. Contrarily, one of the goals of this research project is to complement their works, ${ }^{42}$ and provide the reader with an alternative way to understand the song's pitch structure composed of types A-1, A-2, B, and C orthography.

Finally, to conclude this paper, I would like to propose several questions to the analyst who is interested in conducting further research on this Lied or other atonal songs by Webern. Even though my analysis demonstrates the way Webern profoundly uses pitch orthography to articulate the text setting and musical form, how would we respond to the claim that the accidentals are chosen to make the vocal line easier to sing? Suppose we replace Webern's notations involving accidentals with their enharmonic equivalents, wouldn't that make the singer's task more difficult? Let me provide an example here. At the end of Part B (mm. 17-18, see Example 5, verse (3) line 4), the last two pitches are C-sharp -E-natural $_{4}$. Is it easier to sing a major sixth than a diminished seventh (D-flat - E-natural $)_{4}$, , so Webern notates the pitch E-natural 4 instead of D-flat 5 ? Moreover, how does my pitch orthography analysis figure into op. 12 as a whole (there are three more songs in this opus: nos. 1, 3, and 4)? Or, to extend this question, there are twenty-eight more songs created in the period (1914-1926) when Webern was prolifically writing

40. I must point out that throughout the song, the pitch-class A-sharp is the only missing note from type A-2. This observation invites a further conversation among analysts who are interested in pitch orthography in this song, offering them a future direction to investigate the reason of the missing pitch-class A-sharp.

41. The representative type of this work is Forte, "The New Lieder: Four Songs for Voice and Piano, Opus $12, " 256-266$.

42. As Ian Bent ("Analytical Method: Set-Theory Analysis," in Analysis, with a Glossary by William Drabkin [New York and London: W. W. Norton \& Company, 1987], 100-108) would likely argue, set-theory analysis "has been formulated with rigour and comprehensiveness," and it "offers a powerful and penetrating tool" for music analysis. To support Bent's argument, the following presents one strength of applying set-theory to analyze this song. Despite of the difference in pitch spelling, all the pitch-classes in the cadential chord (mm. 26-28, see Example 2) are exclusively derived from the cross-shape box in Forte's magic rectangle (see Forte, "The New Lieder: Four Songs for Voice and Piano, Opus 12," 266). That is, while pitch-classes 1 and 6 are spelled as C-sharp and F-sharp $_{4}$ in the cadential chord, they are notated as D-flat and G-flat $_{4}$ in the original source of the magic rectangle formed by the three successive 5-21s in $\mathrm{m} 2$. However, if we recognize them to be enharmonically equivalent pitch-classes 1 and 6 , we realize that there is a strong relationship logically and coherently associating this cadential chord with the initial three pentachords. 
Lieder (opp. 12-19) ${ }^{43}$ Will we find a similar pitch spelling consistency underlining the text setting and formal boundary? All these questions beg for answers, which offer the reader and analyst a direction to continue to study Webern's vocal literature. $^{44}$

43. Op. 13 , nos. $1-4$; op. 14 , nos. $1-6$, op. 15 , nos. $1-5$; op. 16 , nos. $1-5$; op. 17 , nos. 1-3; op. 18 , nos. $1-3$; and op. 19, 1-2.

44. It is also worth mentioning that although voice leading is not the main topic of this paper, my categorization of the four note-spelling types A-1, A-2, B, and C, nevertheless, may provide the reader interested in a further study of this song with a means to examine what Joseph Straus ("Voice Leading in Atonal Music," in Music Theory in Concept and Practice, edited by J. M. Baker, D. W. Beach and J. W. Bernard [Rochester: University of Rochester Press, 1997], 237-274) might refer to as the "associational voice leadings" (i. e., associating pitches based on musical context; like register, dynamics, or timbre), because they can be orthographically represented through contextually linking either common or enharmonic pitches within a chord progression. Additionally, on the related topics of associational voice leading, see Alan Chapman, "Some Intervallic Aspects of Pitch-Class Set Relations," Journal of Music Theory 25/2 (Autumn 1981), 275-290; Christopher Hasty, "On the Problems of Succession and Continuity in Twentieth-Century Music," Music Theory Spectrum 8/1 (Spring 1986), 58-74; Allen Forte, "Concept of Linearity in Schoenberg's Atonal Music: A Study of the Opus 15 Song Cycle," Journal of Music Theory 36/2 (Autumn 1992), 285-382; id., "New Approaches to the Linear Analysis of Music," 315-348. 